\title{
CASE STUDY: PSYCHOPRENEUR'S INTENTIONS IN PSYCHOLOGY STUDENTS IN YOGYAKARTA AND JAKARTA
}

\author{
Nia Kusuma Wardhani ${ }^{1 *}$, Reny Yuniasanti ${ }^{2}$, Ratri Pratiwi ${ }^{3}$, Wahyu Kuncoro ${ }^{4}$ \\ Muhammad Iqbal ${ }^{5}$ \\ 1,2,3,4 Universitas Mercubuana, Yogyakarta, Indonesia \\ ${ }^{5}$ Universitas Mercubuana, Jakarta, Indonesia \\ *Corresponding Author: niakusumawardhaniumby@gmail.com \\ Info Artikel \\ Sejarah Artikel: \\ Diterima:16/12/2021 \\ Direvisi : 24/12/2021 \\ Disetujui:30/12/2021 \\ Keywords: \\ Psychoprenuer's \\ intentions; \\ Psychopreneur's intention \\ factors, Psychology \\ students \\ Kata Kunci: \\ Psychoprenuer's \\ intentions; faktor-faktor \\ intensi psychoprenenur, \\ Mahasiswa psikologi \\ Abstract. The character of an entrepreneur is reflected as an individual who is able to \\ take risks and opportunities actively, creatively, innovatively, empowered, creative, \\ initiative, leadership abilities, and initiative in new ways of acting. Entrepreneurship in \\ the field of educational psychology is called psychoprenuer. The low level of student \\ intention to entrepreneurship, especially in the field of psychology development, so the \\ purpose of this study was to determine the level and factors of psychoprenuer intentions in \\ psychology students in Yogyakarta and Jakarta. The research method was qualitative with \\ a two-stage case study approach, namely analyzing the psychoprenuer intention scale and \\ the factors that influence psychoprenuer intentions in psychology students in Yogyakarta \\ and Jakarta. Development of the psychoprenuer interview intention instrument as a form \\ of instrument data multiplication. Then testing the psychoprenuer intention level with the \\ previously developed psychoprenuer intention scale. The data collection method in this \\ study used a purposive sampling method with the sample criteria of students in the \\ psychology department. Higher education can be a factor that influences the increase in \\ the intention of psychology students to become psychopreneurs. To encourage students' \\ intentions to become psychopreneurs, it is necessary to formulate a curriculum with \\ related fields, this needs to be reviewed so that psychology graduates are able to adapt to \\ the digital era and become a solution during the COVID-19 pandemic. Several factors \\ that influence entrepreneurial intentions such as environment, family, education, personal \\ values, age and gender. Environment, family and education are external factors while \\ personal values, age and gender are internal factors that influence individual intentions to \\ become entrepreneurs.
}

Abstrak. Karakter seorang wirausaha diceminkan sebagai individu yang mampu mengambil resiko dan peluang secara aktif, kreatif, inovatif, berdaya, bercipta, berkarsa, kemampuan kepemimpinan, dan inisiatif dalam cara baru dalam bertindak. Kewirausahaan di bidang psikologi pendidikan disebut dengan istilah psychoprenuer. Rendahnya tingkat intensi mahasiswa untuk berwirausaha terutama bidang pengembangan psikologi, sehingga tujuan penelitian ini adalah mengetahui tingkatan dan faktor-faktor intensi psychoprenuer pada mahasiswa psikologi di Yogyakarta dan Jakarta. Metode penelitian adalah kualitatif dengan pendekatan studi kasus dua tahap yaitu analisis skala intesi psychoprenuer dan faktor-faktor yang mempengaruhi intensi psychoprenuer pada mahasiswa jurusan psikologi di Yogyakarta dan Jakarta. Pengembangan instrument intensi psychoprenuer wawancara sebagai bentuk pengalian data instrumen. Kemudian pengujian tingkat intensi psychoprenuer dengan skala intensi psychoprenuer yang telah dikembangkan sebelumnya. Metode pengumpulan data pada penelitian ini menggunakan metode purposive sampling dengan kriteria sampel mahasiswa pada jurusan psikologi. Pendidikan perguruan tinggi dapat menjadi faktor yang berpengaruh terhadap peningkatan intensi mahasiswa psikologi untuk menjadi psychopreneur. Untuk mendorong intensi mahasiswa manjadi psychopreneur perlu dirumuskan dalam kurikulum dengan bidang yang terkait, hal ini perlu ditinjau agar lulusan psikologi mampu beradaptasi pada era digital dan menjadi solusi pada masa pandemi Covid-19. Beberapa faktor yang mempengaruhi niat berwirausaha seperti lingkungan, keluarga, pendidikan, nilai-nilai pribadi, usia dan jenis kelamin. Lingkungan, keluarga dan pendidikan merupakan faktor eksternal sedangkan nilai pribadi, usia dan jenis kelamin merupakan faktor internal yang mempengaruhi niat individu untuk menjadi wirausaha.

How to Cite: Wardhani, N.K., Yuniasanti, R., Pratiwiri, R., Kuncoro, W., \& Iqbal, M. (2022). CASE STUDY: PSYCHOPRENEUR'S INTENTIONS IN PSYCHOLOGY STUDENTS IN YOGYAKARTA AND JAKARTA. Prima Magistra: Jurnal Ilmiah Kependidikan, 3(1), 100-105. https://doi.org/10.37478/jpm.v3i1.1445
Alamat korespondensi:
Penerbit:
Universitas Mercubuana Yogyakarta. Jln. Raya Wates, DIY Program Studi PGSD Universitas Flores
Q) niakusumawardhaniumby@gmail.com 


\section{INTRODUCTION}

Unemployment in Indonesia is caused by the impact of the Covid-19 pandemic. Many companies are reducing the number of workers, and increasing the number of new workers who are not yet employed. BPS (2020) data records the number of unemployed based on education level that $5.73 \%$ are university graduates and $6.76 \%$ are diploma I/II/III graduates. This shows that higher education graduates do not guarantee someone has a job. The same as students studying psychology. Although the number of psychological health workers in Indonesia is still very much needed. WHO sets the standard for the number of psychologists and clinical psychologists with a population of $1: 30,000$. So it takes about 7,500 psychologists for 250 million Indonesian people. Meanwhile, according to the Indonesian Clinical Psychology Association (IPK), the number of clinical psychologists they have verified as of May 5, 2019 is only around 1,143 people (Adam, 2019). Another thing is evidenced by data on the prevalence of people aged 15 years and over who experience depression by $6 \%$, or about 14 million people and only $9 \%$ of people with depression who take medication or undergo medical treatment (Kemenkes, 2018). The low number of people with mental disorders who receive health services is the reason that it is necessary to increase the number of mental health services, one of which is the presence of psychologists.

Based on PPDIKTI data in the 2018/2019 academic year reporting, there are currently 83,230 psychology students who are actively registered in 240 universities in Indonesia (Adam, 2019). The amount is large enough to meet the needs of psychologists in Indonesia. However, the obstacle is that not all psychology students continue their professional education to become psychologists. This is due to the high cost of education in psychology study programs, in Jabodetabek it is estimated that the cost of education is Rp. 14-25 million per semester (Adam, 2019). In addition, the COVID-19 pandemic has changed psychologists to continue to provide face-to-face services to online services, ranging from psychological tests/assessments, training, psychoeducation, counseling, psychotherapy and consultations. In facing the challenges of the COVID-19 pandemic and the digital era, not all psychology practitioners are able to accept or adapt to online/online work patterns, there are some psychology practitioners who close services. This is due to the low level of digital literacy (Adam, 2019).

Entrepreneurial psychology research has relevance and urgency, especially for the advancement of the business world. But unfortunately, this is not practiced by psychology experts and students in Indonesia, it can be seen from the lack of scientific publications in this field, the monotony of the problems raised in existing research and research subjects that are not representative.

The problem is the government by making a policy in the form of Government Regulation No. 17 of 2010 the aim of higher education is to form people who are critical, creative, innovative, independent, confident and entrepreneurial.

Munawaroh \& Rimiyati (2016) say entrepreneurship is a mental attitude and soul that is active, creative, empowered, creative, initiative and humble in business in order to increase income in its business activities or work. Psychology alumni who have the mentality of being entrepreneurs are called Psycho Entrepreneurs or entrepreneurship in the field of psychology (Saptaria \& Setyawan, 2021).

Psycholopreneur intention is one of important thing to support entrepreneurship (Montiel-Méndez \& del Carmen ÁlvarezCastañón, 2019). Its also of students's in Jakarta and Yogyakarta have diferent character. It showed data of observation that most of student in both of them study while job in nigh time or doing online shop by social media, status, website or market place as like facebook, shopee, tokopedia, blibli, buka lapak, and ect (Lupi \& Nurdin, 2016). That data was contra productive in the filed that in tulungagung. Hastuti \& Setyawan (2021) said that only $31 \%$ of final year students have high entrepreneurial intentions. proves that not many students have the desire 
and hope to become entrepreneurs or open their own businesses. The university teaches adequate knowledge and inspiration for entrepreneurship will increase students choosing an entrepreneurial career. Moreover, entrepreneurship education plays an important role in fostering and promoting entrepreneurial activity.

This condition makes it interesting for further research to be carried out so that the development of psychopreneurs is more developed and advanced so that they can contribute to the treasures of knowledge, methods and strategies for psychopreneurs. It also opens up new business and job opportunities. This is also a special interest for the research team to find a new concept of real psychopreneurs (Yuniasanti \& Verasari, 2015).

\section{METHODS}

This study used a purposive sampling data collection with the criteria of participants were students majoring in psychology in Yogyakarta and Jakarta. The psychoprenuer intention scale that had been developed to test the level of psychoprenuer intention in psychology students. The number of samples planned was 200 psychology students in Yogyakarta and 200 psychology students in Jakarta. This research method will be divided into 3 stages, namely 1 . Development of psychoprenuer intention scale instrument, 2. Intensity level testing, 3. Testing of psychoprenuer intention factors. Factors that influence psychoprenuer intentions such as age, gender, place of domicile, and university origin were tested in this study.

\section{RESULTS AND DISCUSSION}

\section{The Process of Formation of Psychopreneur Intentions}

The Entrepreneurship process according to Baron (1998) has 3 important stages, First, identification of opportunities (opportunity identification), Second, execution of a business, Third, managing and developing a business. Psychological aspects play a very important role in these three phases. In general, the individual aspect plays a bigger role in the first phase, then the influence is less when the company has entered the third period. The process of forming entrepreneurial intentions in a person goes through several stages before the formation of entrepreneurial intentions. The desire factor (motivation) to achieve something is to encourage individuals to succeed. Individuals who have a high need for achievement are bold in the decisions they make. A high desire to succeed in achieving something forms the individual's selfconfidence and high self-control (Locus of control).

\section{Aspects of Psychopreneur Intention}

a. Behavioral beliefs are the basis for the formation of subjective norms. Attitude is a factor that exists in a person who is learned to respond in a consistent way, namely liking or disliking an assessment of a given. Evaluation is the result of the behavior of the assessment given by the individual to each result or result obtained by the individual. Whether or not they display certain behaviors, this evaluation can be beneficial or detrimental.

b. Subjective norm, is a person's perception of the thoughts of the parties who are considered to play a role and have hopes for him to do something with the desire to fulfill these expectations. Normative beliefs, namely individual beliefs about norms, people around them and individual motivation to follow these norms.

c. Behavioral control, which is a reference to the difficulty or ease of a person in certain behavior. Behavioral control plays an indirect role in influencing behavior, namely through intentions towards behavior. Behavioral control, which is the basis for the formation of perceived behavioral control. Perceived behavioral control is the perception of the strength of factors that facilitate or complicate.

\section{Factors Affecting Entrepreneurial Intentions}

a. Family and social environment

Parents will provide a cultural style, home atmosphere, outlook on life and socialization patterns that will determine attitudes, behavior and educational processes 
for their children. Parents who work as entrepreneurs will support and encourage independence, achievement and responsibility. Support for these parents, especially fathers, is very important in making career choices for children.

\section{b. Education}

The importance of education is stated by Holt (Khoir et al., 2020) who says that the entrepreneurship education package will shape students to pursue entrepreneurial careers. Formal education provides a better understanding of the entrepreneurial process, the challenges new venture founders face and the problems that must be overcome in order to be successful. Meanwhile, according to Sari \& Setiawan (2021), education is important for entrepreneurs, not only the degree they get, but education also has a big role in helping to overcome problems in business such as investment decisions and so on.
Several studies have found that entrepreneurs have different attitudes towards management processes and business in general (Hisrich et al., 1998). Personal values are shaped by individual motivation and optimism. Research by Indarrti \& Kristiansen (2003) found that the level of entrepreneurial intention of students is influenced by the level of motivation, self-control and optimism of students. Thus, personal values also determine the level of one's entrepreneurial intentions.

d. Age

Strong's research in (Potishuk \& Kratzer, 2017) on a number of men aged 1525 years on interest in work shows that interest changes moderately and rapidly at the age of 15-25 years and there is very little change thereafter. Potishuk and Kratser (2017) also add that age has a significant effect on entrepreneurial intentions among students.

\section{c. Personal Value}

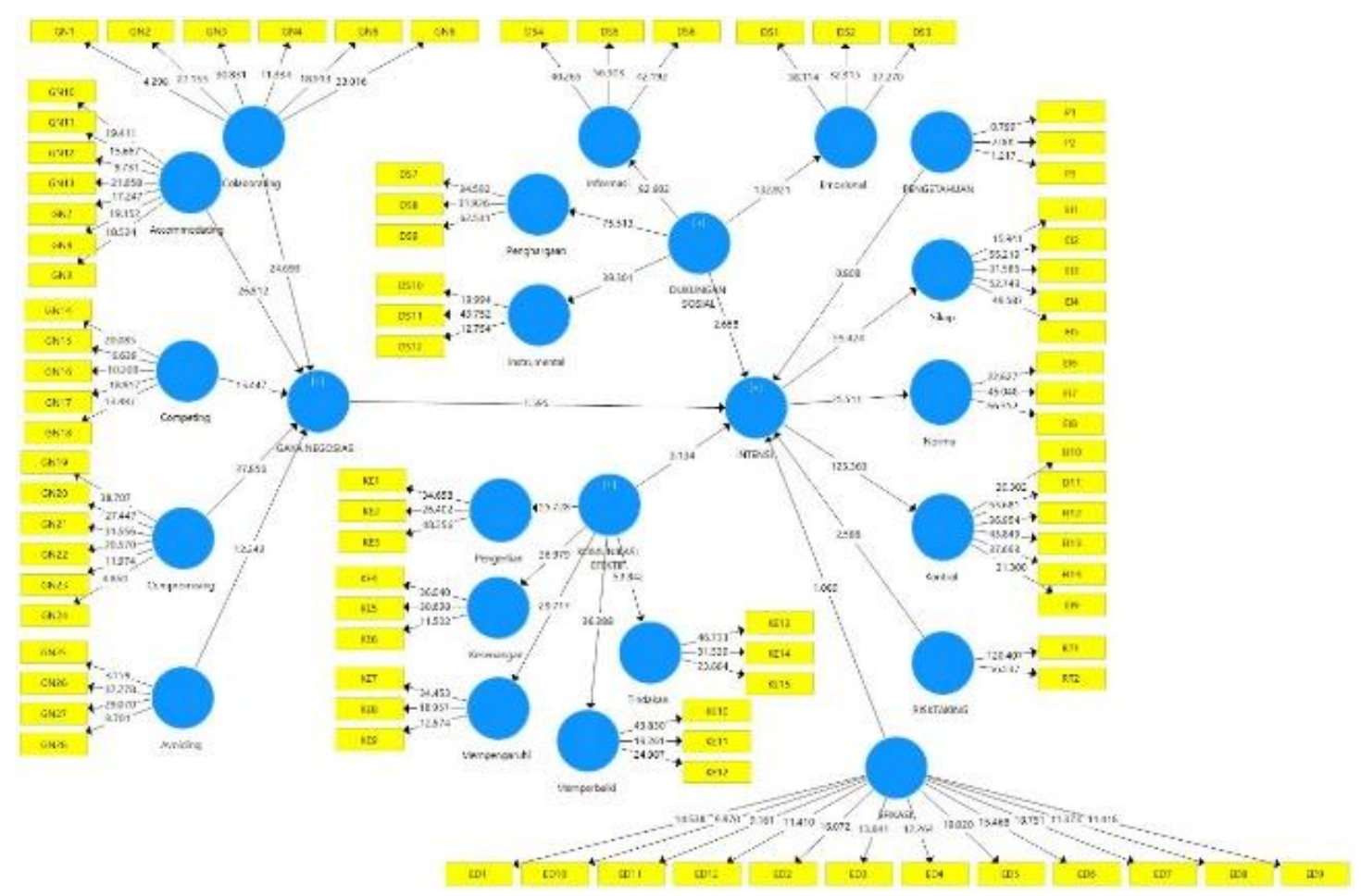

Figure 1. Connectivity Psychopreneur's Intentions in Psychology Students

e. Gender

Gender is very influential on the interest in entrepreneurship given the differences in the views of work between men and women. Setyawan (2020) suggest that most women tend to be casual in choosing jobs compared to men. Women think work is not important. Because women are still faced with greater traditional demands of being wives and housewives. In addition to the 
Nia Kusuma Wardhani, Reny Yuniasanti, Ratri Pratiwiri, Wahyu Kuncoro, Muhammad Iqbal

Case Study: Psychopreneur's Intentions in Psychology Students in Yogyakarta and Jakarta

Prima Magistra: Jurnal Ilmiah Kependidikan Volume 3, Nomor 1, Januari 2022, hal 100-105

factors that influence entrepreneurial achievement, the motive for affiliation intentions above, an entrepreneur has three (making friendships), and the motive for basic social motives: the motive for power.

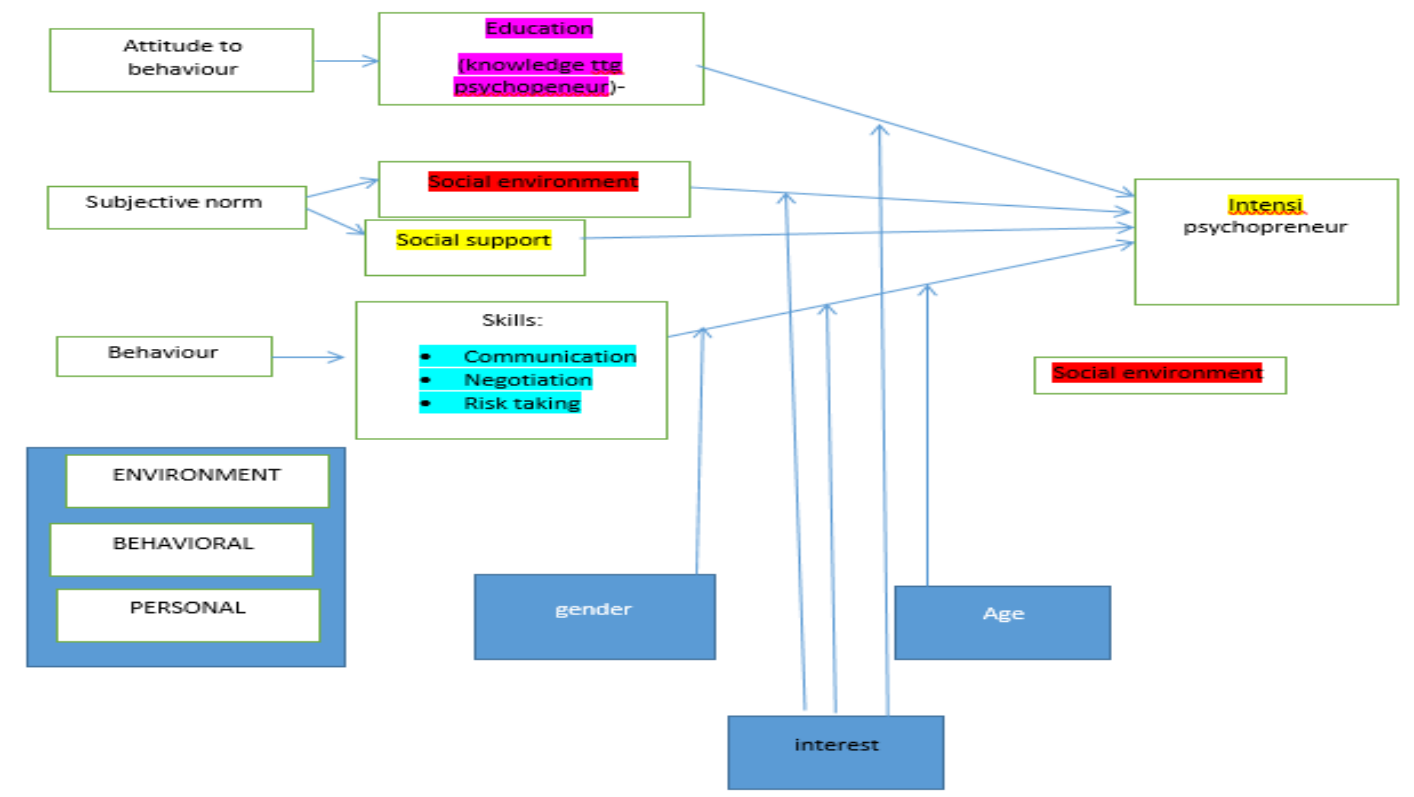

Figure 2. Correlation Factors for Achieving Psychopreneur (Source: Instrumen Monev Learning Device (Adopted))

Figure 1 showed that result of data questioner mention correlation family and social environment, education, personal value, age and gender effect of some one be mature to decide of implementation psychopreneurhip in their life. Figure 2 showed that to be mature in psychopreneurship had known behavior of communication, negotiation, and risk taking. Person be able to develop of attitude to behavior by education, environment and social support (Setyawan \& Nawangsari, 2021).

\section{CONCLUSIONS AND SUGGESTIONS}

It can be concluded that there are several factors that influence entrepreneurial intentions in Jakarta and Yogjakarta such as environment, family, education, personal values, age and gender. Environment, family and education are external factors while personal values, age and gender are internal factors that influence individual intentions to become entrepreneurs.

\section{REFERENCES}

Adam, A. (2019). Pekerja Kesehatan Mental Banyak Peminat, tapi Kuliahnya Mahal. https://tirto.id/pekerja- kesehatan-mental-banyak-peminat-tapikuliahnya-mahal-dpkw

Baron, R. A. (1998). Cognitive mechanisms in entrepreneurship: Why and when enterpreneurs think differently than other people. Journal of Business Venturing, 13(4), 275-294. https://doi.org/https://doi.org/10.1016/S 0883-9026(97)00031-1

BPS. (2020). Tingkat Pengangguran Terbuka (TPT).

https://www.bps.go.id/pressrelease/202 0/11/05/1673/agustus-2020--tingkatpengangguran-terbuka--tpt--sebesar-707-persen.html

Hastuti, S. W. M., \& Setyawan, W. (2021). Community Service in Study Potential Technology of Education Tour and Business Prospects of Traders in Tulungagung. Mitra Mahajana: Jurnal Pengabdian Masyarakat, 2(2), 134144.

https://doi.org/10.37478/mahajana.v2i2. 952

Hisrich, R. D., Peters, M. P., \& Shepherd, D. A. (2008). Kewirausahaan Edisi 
7. Edisi Bahasa Indonesia. Jakarta: Salemba Empat. Google Scholar

Indarti, N., \& Krinstiansen, S. (2003). Determinants of entrepreneurial intention: The case of Norwegian students. Gadjah Mada International Journal of Business, 5(1), 79-95. https://doi.org/10.22146/gamaijb.5392

Kemenkes. (2018). Laporan Nasional Riskesdas 2018. Jakarta: Lembaga Penerbit Badan Penelitian dan Pengembangan Kesehatan. Google Scholar

Khoir, A., Suhandi, S., Sudarsono, A., Rahmawati, E., \& Purwanti, P. (2020). Membangun Generasi Unggul Melalui Penyuluhan Dan Pelatihan Kewirausahaan Bagi Pemuda Karang Taruna Rt/Rw: 004/013 Kebon Duren Kelurahan Ciputat. Jurnal Pengabdian Dharma Laksana, 3(1), 85-91. https://doi.org/http://dx.doi.org/10.3249 3/j.pdl.v3i1.6305

Lupi, F. R., \& Nurdin, N. (2016). Analisis Strategi Pemasaran Dan Penjualan ECommerce Pada Tokopedia. Com. Jurnal Elektronik Sistem Informasi Dan Komputer, 2(1), 20-29. http://jesik.web.id/index.php/jesik/articl e/view/43

Montiel-Méndez, O. J., \& del Carmen Álvarez-Castañón, L. (2019). Entrepreneurship from a Business Incubator of a Public University supported by a Psychological Program. In Societal entrepreneurship and competitiveness. Emerald Publishing Limited.https://doi.org/10.4018/978-15225-7675-4.ch006

Munawaroh, M., \& Rimiyati, H. (2016). KEWIRAUSAHAAN.

http://repository.umy.ac.id/bitstream/ha ndle/123456789/3495/KEWIRAUSAH AAN.pdf?sequence $=1$

Potishuk, V., \& Kratzer, J. (2017). FACTORS AFFECTING ENTREPRENEURIAL
INTENTIONS

AND

ENTREPRENEURIAL ATTITUDES

IN HIGHER EDUCATION. Journal of Entrepreneurship Education, 20(1). Google Scholar

Saptaria, L., \& Setyawan, W. H. (2021). Desain Pembelajaran

Technopreneurship Untuk

Meningkatkan Motivasi Berwirausaha Mahasiswa Uniska Kediri. Prima Magistra: Jurnal Ilmiah Kependidikan, 2(1), $\quad$ 77-89. https://doi.org/https://doi.org/10.37478/ jpm.v2i1.880

Sari, H. P., \& Setiawan, W. H. (2021). Peningkatan Teknologi Pendidik Pesantren Anak Sholeh melalui MEMRiSE: Coaching \& Training. Prima Abdika: Jurnal Pengabdian Masyarakat, 1(3), 81-90. https://doi.org/10.37478/abdika.v1i3.11 23

Setyawan, W. (2020). Qualified Lecturers Must Update By Educational Technology. In Initiative of Thoughts from Indonesia to the World of the Covid 19 era (pp. 175-181). novateurpublication.

https://novateurpublication.com/wpcontent/uploads/2020/09/28.WAWAN-HERRY-SETYAWAN.pdf

Setyawan, W. H., \& Nawangsari, T. (2021). Pengaruh E-Module Speaking Berbasis Website Untuk Meningkatkan Keterampilan Berbicara. Aksara: Jurnal Ilmu Pendidikan Nonformal, 7(2), 339346. https://doi.org/http://dx.doi.org/10.3790 5/aksara.7.2.339-346.2021

Yuniasanti, R., \& Verasari, M. (2015). Intensi Berwirausaha Pada Mahasiswa Tingkat Akhir. Psikologika: Jurnal Pemikiran Dan Penelitian Psikologi, 20(1), 91-99. https://journal.uii.ac.id/Psikologika/arti cle/view/7713 